\title{
WORKSHOP PENYUSUNAN PROGRAM UNGGULAN MADRASAH
}

\author{
HAROMAIN $^{1}$, RUDI HARIAWAN ${ }^{2}$, MUHAMMAD SUHARDI ${ }^{3}$ \\ 1,2,3Program Studi Administrasi Pendidikan Universitas Pendidikan Mandalika
}

Email : haromain@undikma.ac.id

\begin{abstract}
ABSTRAK
Pengabdian ini bertujuan untuk memberikan edukasi bagi tenaga pendidik dan kependidikan dilingkup madrasah dan menghasilkan program-program unggulan yang akan dilaksanakan oleh setiap warga madrasah. Peserta dalam kegiatan pengabdian yang terdiri atas tenaga pendidik dan kependidikan di lingkungan Pondok Pesantren Nahdlatul Mujahidin sangat antusias dalam memberikan ide, pemikiran dan konsep yang diharapkan sebagai lembaga pendidikan yang efektif. Peningkatan kemampuan akademik siswa, pengembangan budaya madrasah serta penguatan karakter siswa menjadi acuan umum dalam menyusun programprogram yang sesuai dengan keadaan madrasah.
\end{abstract}

Katakunci: program unggulan, madrasah efektif, budaya madrasah.

\section{PENDAHULUAN}

Penyelenggaraan pendidikan pada dasarnya merupakan tanggung jawab pemerintah dan masyarakat. Peran serta masyarakat dalam pengelolaan dan penyelenggaraan lembaga pendidikan sebagaimana diatur dalam Undang-Undang No. 20 Tahun 2003 tentang Sistem Pendidikan Nasional memberikan posisi dan peran serta masyarakat secara penuh dalam menyelenggarakan pendidikan dengan kebebasan mengembangkan ciri khas satuan pendidikannya.

Pada pasal 54 ayat 1 dan 2 dijelaskan bahwa: (1) peran serta masyarakat dalam pendidikan meliputi peran serta perseorangan, kelompok, keluarga, organisasi profesi, pengusaha dan organisasi kemasyarakatan dalam penyelenggaraan dan pengendalian mutu layanan pendidikan; (2) masyarakat dapat berperan serta sebagai sumber, pelaksana dan pengguna hasil pendidikan. Lebih lanjut dalam pasal 55 ayat 1 dijelaskan bahwa "masyarakat berhak menyelenggarakan pendidikan berbasis masyarakat pada pendidikan formal dan nonformal sesuai dengan kekhasan agama, lingkungan sosial dan budaya untuk kepentingan masyarakat".

Dalam prakteknya, terdapat banyak lembaga kemasyarakatan yang terlibat dan mengambil peran dalam penyelenggaraan pendidikan di Indonesia. Berbagai yayasan sebagai badan penyelenggara pendidikan mendirikan satuan-satuan pendidikan dalam berbagai jenjang, mulai dari jenjang pendidikan dasar hingga pendidikan tinggi.

Namun keberadaan lembaga-lembaga pendidikan swasta yang kekinian semakin berkembang belum sepenuhnya diikuti oleh manajemen yang profesional dalam pengelolaannya. Lembaga-lembaga pendidikan swasta ini cenderung berada pada kelas kedua bila dibandingkan dengan lembaga-lembaga pendidikan yang pengelolaannya sepenuhnya di handle oleh pemerintah.

Terdapat banyak persoalan yang dihadapi oleh lembaga pendidikan dalam melaksanakan kegiatan operasionalnya. Beberapa diantaranya adalah: pertama, kemampuan sumber daya manusia yang dimiliki masih terbatas. Kedua, kemampuan finansial pengelola dalam mendukung operasional lembaga masih minim. Ketiga, terbatasnya jaringan yang dimiliki oleh pengelola dalam menjalin kemitraan untuk meningkatkan kualitas. Keempat, program yang ditawarkan tidak didukung oleh kompetensi sumber daya manusianya. Kelima, kesejahteraan karyawan yang masih belum terpenuhi (Haromain, 2013). Persoalan-persoalan yang dihadapi oleh lembaga pendidikan swasta ini secara tidak langsung berpengaruh terhadap kinerja operasional lembaga yang tentunya berdampak pada kualitas luaran yang dihasilkan tidak maksimal atau mencapai target yang diharapkan.

Nusa Tenggara Barat merupakan salah satu provinsi dengan jumlah sekolah swasta yang cukup besar. Keberadaan sekolah swasta di propinsi ini cukup memberi andil bagi 
perkembangan pendidikan. Sekolah-sekolah swasta ini dalam perkembangannya mengalami pasang surut. Persaingan untuk memperoleh input yang berkualitas cukup signifikan. Sebagai bagian dari masyarakat, sekolah swasta yang dengan motto-nya "lahir dari masyarakat dan untuk masyarakat" harus mampu menjawab setiap tantangan yang dihadapi ditengah-tengah masyarakat.

Sekolah swasta sebagai salah satu lembaga pendidikan masyarakat yang keberadaannya dikelola oleh swasta, dalam praktiknya harus mampu mempertahankan eksistensinya sehingga keberadaannya tetap diakui oleh masyarakat. Kondisi riil di lapangan banyak ditemukan adanya sekolah swasta yang justru tidak mampu mengikuti perkembangan. Faktor regenerasi sumber daya manusia yang gagal memperlihatkan kondisi yang boleh dikata "hidup segan mati tak mau". Keberadaan sekolah swasta dengan kondisi seperti ini hanya tinggal menunggu waktu untuk lenyap hingga terlupakan oleh masyarakat. Maka penting dalam hal ini sekolah menyiapkan program-program berkualitas yang tentunya mampu untuk mempertahankan eksistensinya ditengah masyarakat.

Target dan luaran yang diharapkan dari kegiatan pengabdian masyakat ini antara lain: 1) warga madrasah memahami konsep madrasah yang efektif dan unggul, 2) setiap warga sekolah memiliki kesadaran akan pentingnya mengembangkan program unggulan sebagai upaya mempertahankan eksistensi madrasah ditengah masyarakat, 3) tersusunnya program unggulan yang dimiliki oleh madrasah.

\section{METODE PENGABDIAN}

Dalam melaksanakan kegiatan pengabdian dengan tema workshop penyusunan program unggulan madrasah, terdapat beberapa tahapan yang di lakukan, yaitu:

\section{Tahap Persiapan}

Pada tahap ini dilakukan koordinasi antara tim pengabdian yang terdiri dari dosen Program Studi Administrasi Pendidikan FIPP Undikma dengan pengurus Pondok Pesantren Nahdlatul Mujahidin NW Jempong dan kepala-kepala lembaga yang ada dibawahnya (RA, MI, MTs dan Panti Asuhan) untuk merencanakan pelaksanaan kegiatan secara konseptual, operasional, serta job description masing-masing. Tim pengabdian dan kepala-kepala lembaga selanjutnya melebur kedalam satu kepanitiaan yang selanjutnya membagi tugas masing-masing sesuai dengan perannya.

\section{Tahap Pelaksanaan Workshop}

Pada tahap ini, terdapat dua sesi kegiatan, yaitu:

\section{a. Penyajian Materi}

Materi yang disajikan terkait program-program unggulan madrasah yang dapat menjadi dasar bagi lembaga dalam mempromosikan lembaga kepada pihak-pihak terkait. Materi-materi tersebut antara lain:

\begin{tabular}{|l|l|l|}
\hline No & \multicolumn{1}{|c|}{ Materi } & \multicolumn{1}{c|}{ Pemateri } \\
\hline 1 & Mengembangkan Madrasah Efektif & Dr. Muhammad Suhardi, M.Pd \\
\hline 2 & $\begin{array}{l}\text { Strategi dan Arah Pengembangan Madrasah } \\
\text { Unggul }\end{array}$ & Dr. Rudi Hariawan, M.Pd \\
\hline 3 & Stategi Penyusunan Program Madrasah Unggul & Dr. Haromain, M.Pd \\
\hline
\end{tabular}

\section{b. Penyusunan Program Unggulan}

Dalam penyusunan program unggulan madrasah, setiap lembaga di bawah koordinasi kepala madrasah dengan beranggotakan guru dan staf pada masing-masing madrasah mengelompokkan diri untuk merancang program-program yang sesuai dengan situasi dan kondisi masing-masing madrasah. Pada tahap ini, setiap madrasah menyusun profil madrasah yang terdiri dari visi, misi, tujuan, standar mutu lulusan, kurikulum serta pengembangan diri.

Dalam proses penyusunan program unggulan ini, disepakati tiga aspek yang menjadi fokus diskusi diantara masing-masing lembaga yang selanjutnya menjadi kesepakatan bersama. Ketiga aspek tersebut yaitu: 1) program unggulan pada aspek akademik, 2) program unggulan pada aspek budaya madrasah, dan 3) program unggulan pada aspek penanaman karakter. 
Ketiga aspek tersebut selanjutnya diplenokan dan didiskusikan dengan pengurus pondok pesantren, guru dan staf yang ada pada semua madrasah untuk selanjutnya disahkan menjadi program yang harus di jalankan oleh setiap warga madrasah.

\section{Refleksi Kegiatan Workshop}

Pada tahap ini, dilakukan pengkajian dan diskusi diantara semua peserta workshop tentang kegiatan yang dilaksanakan. Dari proses diskusi tersebut dapat dilihat antusiasme peserta workshop yang cukup tinggi terhadap program-program yang ingin dilaksanakan. Berbagai usulan dan tanggapan terhadap rencana program-program unggulan yang akan dilaksanakan direspon cukup baik. Peserta workshop yang merupakan tenaga pendidik dan kependidikan di lingkungan Pondok Pesantren Nahdlatul Mujahidin NW Jempong karena merasa dilibatkan sehingga rasa memiliki terhadap keberadaan pondok pesantren tertanam didalam jiwa mereka.

\section{HASIL DAN PEMBAHASAN}

Program uunggulan madrasah merupakan salah satu aspek yang cukup berpengaruh terhadap eksistensi sebuah lembaga pendidikan swasta yang lahir dari rahim masyarakat. Menurut Zarkasyi (2016) program unggulan adalah suatu rangkaian langkah yang dilaksanakan dengan urutan tertentu untuk mencapai keunggulan dalam luaran (output) pendidikannya Program unggulan yang dimiliki oleh madrasah dapat menjadi daya tarik yang mampu memikat hati orang tua untuk menyekolahkan anak-anaknya dimadrasah. Setiap madrasah harus memiliki program unggulan masing-masing. Dimana program unggulan yang dimiliki untuk mewadahi seluruh siswanya yang ingin mengembangkan potensi yang dimiliki sehingga bisa berprestasi.

\section{a. Program Unggulan pada Aspek Akademik}

Komponen akademik menjadi bagian yang sangat penting dalam pengembangan diri setiap siswa. Pada aspek ini, madrasah menyusun program unggulan antara lain: penguatan kemampuan anak dalam penguasaan IT, penguasaan bahasa asing (arab, inggris), penguasaan sains (matematika dan IPA), tentor teman sebaya, pengayaan olimpiade (sains, matematika, Bahasa inggris, Bahasa arab, dan IPS), pembinaan kemampuan menulis serta pamantapan bimbingan belajar intensif.

\section{b. Program Unggulan pada Aspek Budaya Madrasah}

Budaya madrasah merupakan keseluruhan pengalaman psikologis yang dimiliki oleh siswa yang berkaitan dengan aspek sosial, emosional maupun intelektual yang diperolehnya selama berada dilingkungan madrasah. Respon psikologis terhadap apa yang dilihat, didengar dan dirasakan oleh siswa dalam kesehariannya dimadrasa menjadi pelajaran berharga baginya untuk bersikap dan berprilaku dalam kehidupannya.

Kebijakan madrasah yang berkaitan dengan kondisi dan layanan yangb diperoleh siswa, penataan lingkungan madrasah, kenyamanan setiap warga madrasah adalah hal penting yang menjadi perhatian dalam membentuk budaya madrasah. Budaya madrasah ini tentunya akan melekat pada penghayatan psikologis warga madrasah khususnya siswa yang pada gilirannya nanti akan membentuk nilai, sikap, kebiasaan dan prilakunya.

Adapun program unggulan madrasah yang disusun terkait dengan budaya madrasah antara lain: tahfiz qur'an dan hadist (one day one ayat, one day one hadist), sholat dhuha, sholat zuhur berjamaah, keputrian, Budaya 5S (Senyum, Salam, Sapa, Sopan dan Santun), budaya tertib, disiplin dan rapi, serta penegakan tata tertib madrasah.

\section{c. Program Unggulan pada Aspek Penanaman Karakter}

Penguatan Pendidikan Karakter (PPK) merupakan gerakan pendidikan di bawah tanggung jawab sekolah untuk memperkuat karakter peserta didik melalui harmonisasi olah hati (etik), olah rasa (estetik), olah pikir (literasi), dan olah raga (kinestetik) dengan dukungan pelibatan publik dan kerja sama antara sekolah, keluarga, dan masyarakat yang merupakan bagian dari Gerakan Nasional Revolusi Mental (GNRM). 
Adapun program unggulan madrasah yang disusun antara lain: pesantren Ramadhan, Latihan Kepemimpinan Siswa (bagi pengurus OSIM), Peringatan Hari Besar Islam (PHBI), Peringatan Hari Besar Nasional (PHBN), market day, dsb.

\section{KESIMPULAN}

Kegiatan pengabdian pada masyarakat dalam bentuk workshop penyusunan program unggulan madrasah ini mendapat respon yang cukup baik dari setiap peserta. Antuasisme peserta workshop tampak dalam setiap tahapa proses yang dilaksanakan. Hal ini juga merupakan salah satu bentuk pelibatan peserta yang terdiri dari pengurus pondok pesantren, tenaga pendidik dan kependidikan dalam upaya memajukan madrasah serta mempertahankan eksistensinya ditengah masyarakat. Dari kegiatan ini telah tersusun program-program unggulan madrasah yang selanjutnya akan dilaksanakan oleh setiap warga madrasah. Kedepannya perlu dilakukan kegiatan serupa agar setiap warga madrasah merasa memiliki dan bertanggung jawab terhadap keberadaan madrasah. Kemitraan antara akademisi perlu terus dilakukan sehingga jaringan informasi terkait dengan perkembangan Pendidikan dapat diperoleh dengan maksimal.

\section{DAFTAR PUSTAKA}

Carvalho, Carolina dkk. (2014). Teacher Feedback: Educational Guidance in Different School Contexts. Procedia - Social and Behavioral Sciences. Journal 159: 219 diakses 20 Agustus $2021 \mathrm{http}: / / \mathrm{www}$. sciencedirect.com

Dharmayana, I Wayan. (2012). Keterlibatan Siswa (Student Engagement) sebagai Mediator Kompetensi Emosi dan Prestasi Akademik. Jurnal Psikologi Vol 39, No 1 diakses 20 Agustus 2019 https://journal.ugm.ac.id/jpsi/article/view/6968

Hariawan, R. \& Hakim L. (2018). Manajemen Program Unggulan Di Pondok Pesantren. Jurnal Visionary diakses 20 Juni 2021 http://jurnal.ikipmataram.ac.id/index.php/visionary/article/viewFile/694/653

Haromain. (2014). Manajemen Pengembangan Sumber Daya Manusia di Pondok Pesantren. Jurnal Pendidikan Humaniora, Jilid 1 Terbitan No. 2 Hal. 136-149.

Kemdikbud. (2017). Peta Jalan Penguatan Pendidikan Karakter. Jakarta

Zarkasyi, Ahmad. (2016). "Konsep Pengembangan Program Unggulan di Lembaga Pendidikan Islam”. Jurnal Al-Makrifat, Vol 1, No 1. Diakses pada tanggal 30 Juni 2021 